\title{
The Search for Utopia and its Consequences: Political Commitment in Historia de Mayta by Mario Vargas Llosa and The Honorary Consul by Graham Greene
}

\author{
BEATRIZ VALVERDE JIMÉNEZ
}

\begin{abstract}
This article compares the political evolution of Graham Greene and Mario Vargas Llosa, concretely through the analysis of their novels The Honorary Consul (1973) and Historia de Mayta (1984). We examine how, on the one hand, Greene values positively the search for a utopian society of León Rivas, as a means of founding a fairer society. On the other hand, Vargas Llosa, totally disillusioned with his former belief in Socialism, condemns that same search by Alejandro Mayta, since from his point of view, searching a utopian society only leads to failure and death.
\end{abstract}

Keywords: Graham Greene, Mario Vargas Llosa, Utopia, politics, Socialism, disloyalty

DOI: http://dx.doi.org/10.12697/IL.2013.18.1.09

When comparing Mario Vargas Llosa (b. 1936) and Graham Greene (19041991) the first idea that comes to mind is that both authors defined themselves as 'political writers'. Vargas Llosa has stated at various moments of his career that being a writer means having a clear consciousness of one's roots. Unlike most European and Anglo-American writers, for whom the literary act entails the creation of an original work with artistic values, designed to enrich the language and culture of one's country, "[i]n Peru, in Bolivia, in Nicaragua [...] to be a writer means, at the same time, to assume a social responsibility" (Vargas 1978: 6); to become "an active participant in the solution of the economic, political and cultural problems of your society." (Vargas 1978: 6) In these countries, both the media and the academic world have been historically subject to strict censorship by the social and political establishment; thus, literature became the only possible way to denounce social and political injustice: "fiction became a substitute for Social Science." (Vargas 1978: 7) In his address to the Swedish Academy during the Nobel Prize Ceremony (December, 7, 2010), Vargas Llosa insisted on the political power of literature: 
[...] los fabuladores, al inventar historias, propagan la insatisfacción, mostrando que el mundo está mal hecho. [...] Esta comprobación, si echa raíces en la sensibilidad y la conciencia, vuelve a los ciudadanos más difíciles de manipular, de aceptar las mentiras de quienes quisieran hacerles creer que, entre barrotes, inquisidores y carceleros viven más seguros y mejor. (Vargas 2010)

The Peruvian writer also said that he had learned from Sartre "que las palabras son actos y que una novela, una obra de teatro, un ensayo, comprometidos con la actualidad y las mejores opciones, pueden cambiar el curso de la historia.” (Vargas 2010) $)^{1}$

On the other hand, in spite of constantly being called by scholars a 'Catholic author,'2 Graham Greene always stated that he considered himself "more a political writer than a Catholic writer" (Whitman 1992: 58). Greene thought that literature had an important role in a necessary process of social change, "[w] riting is certainly a kind of action" (Allain 1983: 81). "For me political action is writing and nothing else." (Allain 1983: 84) Greene was born and educated, as a person and an artist, in the West. Nonetheless, he was never interested in its political systems per se, based on democracy and competing political parties. On the contrary, like Vargas Llosa, he decided to assume in his writing the mantle of the engaged native writer: "I find myself getting involved in politics that are really a matter of life and death, as they were in the Far East and are in Central America. Where children's lives depend on it." (Lebrecht 1994: 385) "I am interested in such politics and I write about such politics." (Couto 1994: 423)

The belief in the social responsibility of the writer was not their only common trait. Vargas Llosa and Greene also shared in their youth a strong predisposition towards Socialism, which they believed would become the solution for the serious problems suffered for so long by poor countries: "En mi juventud, como muchos otros escritores de mi generación, fui marxista y creí que el socialismo sería el remedio para la explotación y las injusticias sociales que

1 Because of his concept of what literature should be, Vargas Llosa had convinced himself that he was not the appropriate writer to win the Nobel Prize: “¿Por qué? Porque llegué a la conclusión de que yo no estaba en la identikit del Nobel; yo soy un escritor conflictivo, tomo posiciones incómodas, me equivoque o no siempre digo lo que me parecen las cosas, y todo eso me hizo creer que no era el escritor que encajara con la manera de ver la literatura por parte del jurado." (Cruz 2010)

2 In connection to this issue, Cedric Watts states: "Mention the name 'Graham Greene', and the response 'Roman Catholic novelist' comes as readily as the salivation of Pavlov's dog.” (Watts 1997: 155) 
arreciaban en mi país, América Latina y el resto del Tercer Mundo.” (Vargas 2010) Similarly, Greene's name has always been connected to Communism, politically speaking. ${ }^{3}$ He even joined the British Communist Party for a month in 1923 (Allain 1983: 74), during his years at Oxford (1922-1925). ${ }^{4}$ His sympathies towards this political doctrine were evident in his statements: "I don't know, either, how to explain my attraction towards Communism. Deep down, one has always nurtured this dream, perhaps a naïve one, of Communism with a human face." (Allain 1983: 95)

Despite a similar perspective at the beginning of their careers, however, their political viewpoints evolved differently. Vargas Llosa grew disappointed with the evolution of Communism in countries such as the Soviet Union, the Czech Republic, China, and also Cuba, whose revolution he had thought would be very positive for the rest of the continent (Vargas 2010):

Lo que ha pasado y creo que no volverá es la idea socialista de traer el Paraíso a la Tierra, revolucionar radicalmente la sociedad con bases totalmente nuevas, justas, humanas. Esta tradición socialista fue exterminada por el gulag, la violación de los derechos humanos en el llamado socialismo real, su catástrofe económica. [...] Yo creía en aquel socialismo [...] (Vargas 1998: 74)

Rejecting the utopian Socialism which he formerly had believed to be the optimum political doctrine for Latin America, the Peruvian writer ended up becoming "el demócrata y el liberal que soy" (Vargas 2010). Then, he started to defend

[...] la democracia liberal, que, con todas sus limitaciones, sigue significando el pluralismo político, la conciencia, la tolerancia, los derechos humanos, el respeto a la crítica, la legalidad, las elecciones libres, la alternancia en el poder, todo aquello que nos ha ido sacando de la vida feral y acercándonos [...] a la hermosa y perfecta vida que finge la literatura. (Vargas 2010)

3 However, as Maria Couto states, calling Graham Greene 'pro-Communist' is just to simplify his political stance (Couto 1990: 169).

4 Even though there are different versions about his belonging to the British Communist Party, the most widely-held view among scholars is the one offered by Greene himself in Ways of Escape, in which he stated that he joined the Communist Party during one month in 1923, simply because he wanted to travel for free to Moscow (Sherry 1994: 161-162; Solera 1994: 311; Allain 1983: 88). 
Conversely, Greene never rejected Communism completely. He still felt an attraction to its doctrines, because he could see in them: "[...] a desire for justice: a preference for the underdog. With all their faults and their mistakes and the wicked men who have come to power, I feel there remains an idealism in Communism." (Whitman 1992: 58) Greene's expectations, like Vargas Llosa's, were not fulfilled by the development of the Communist system in the Soviet Union or China, which led him to adopt a critical standpoint. Adhering to the central tenet that defines his life and work, what he called "the virtue of disloyalty," he continuously denounced the injustices of Communist regimes. For him, the author's role in society was not to give full support to any doctrine (religious or political), nor to resign oneself to its faults, but to maintain a permanently critical stance:

The writer is driven by his own vocation to be a Protestant in a Catholic society, a Catholic in a Protestant one, to see the virtues of the Capitalist in a Communist society, of the Communist in a Capitalist state. Thomas Paine wrote 'we must guard even our enemies against injustice'. (Greene 1990: 268-269)

As a consequence, Greene never completely identified himself with any political system throughout his life. However, this did not mean that he could not declare himself an admirer of a utopian Communism committed to the search for social justice, in contrast to the aspirations for world domination that he associated with Capitalism (Couto 1994: 413). In fact, when asked in several interviews about his politics, Greene said that he felt close to the Left, but that his definition of it was quite personal (Whitman 1992: 65).

Bearing in mind their political evolution, I would like to analyze The Honorary Consul (1973) and Historia de Mayta (1984), in order to demonstrate how their authors' dissimilar political development is manifested in them. The choice of these two works is due, first, to the fact that they were written when the political standpoint of both authors was totally defined, after the evolution explained above. Second, both novels take place in South America (Paraguay-Argentina in the case of The Honorary Consul, Peru in Historia de

This concept comes from his acceptance speech for the Shakespeare Prize in Hamburg in 1966, where Greene established his personal criterion regarding the artistic commitment any author should take: to make "the work of the State a degree more difficult. That is the genuine duty [writers] owe to society, to be a piece of grit in the State machinery." (Greene 1990: 269) According to the English author, "[d]isloyalty is inherent in politics" (Allain 1983: 80). 
Mayta), during a period of time when guerrilla movements were reaching their climax. Finally, both novels treat the role of revolution and armed conflict in the process of political change in society. After comparing the development of León Rivas and Alejandro Mayta in the novels, as well as the evaluation of the movements they lead, we will see that Vargas Llosa's standpoint is clearly conservative. He condemns the failed revolutionary movement of Jauja because of its utopian basis; and, on the other hand, he discredits the character of Mayta and his political disloyalty, because from his point of view, it is simply not practical. Conversely, Greene's perspective is much closer to a leftist stance: even though his revolutionary action is also destined to fail, the British writer values positively León Rivas' continuous disloyalty to inefficient or corrupt institutions and his search for a more equal society. Differently from Vargas Llosa, thus, Greene rewards utopia in his narrative.

Historia de Mayta is a novel that unveils to the reader its own process. It is a novel about a novel which assumes its form while we are reading it. It also presents simultaneously an analysis of the political ideology and actions that led to the uprising in Jauja in 1958 (Castañeda 1989: 21), the first leftist revolutionary movement in the American continent. ${ }^{6}$ The story is based on the life of Alejandro Mayta, a communist insurrectionary who firmly believes that a revolution is necessary to found a utopian society in which everyone is equal, and where discrimination (based on power, money, gender or sexual option) has ceased to exist. The novel is basically divided into two different temporal dimensions: first, the story of Mayta at the time of the uprising in Jauja (around 1958 according to the novel); and second, about twenty five years later (1983), when a journalist embarks on a research project to reconstruct Mayta's life via interviews with several people who knew him. Through the use of these two timelines the reader compares the socio-political situation of Peru as it was, while simultaneously witnessing the evolution of the Leftist intellectuals since the 1960s. Taking as basis the narrative voice's observation of Peruvian society during the $80 \mathrm{~s}$ (with an atmosphere of increasing political violence), the novel concludes that this situation is just the consequence of the first violent outbreak that took place in Jauja (Zapata 1988: 182; Urdanivia 1986: 136). Moreover, Vargas Llosa himself agreed to this statement and, according to Rita De Grandis, in order to highlight this fact, the Peruvian writer "retrotrae Jauja a 1958 para darle carácter inaugural con respecto a la Revolución Cubana" (De Grandis 1993: 378). The current (1983) situation in Peru, then, is the outcome of the search for revolutionary change through violent methods that started

6 It is important to take into account that this uprising took place in 1962, and not in 1958 as we are told in the novel (Castañeda 1989: 21; De Grandis 1993: 378). 
in the 1950s (Angvik 1992: 94). This is the idea transmitted by the use of the double timeline in the story, since it establishes a continuum between the story of Mayta and the current situation of the country through the testimonies of the interviewed characters and the opinionated voice of the journalist-narrator (Zapata 1998: 182).

The reception of Historia de Mayta among Hispanic scholars (both in Spain and Latin America) from a political point of view, was to consider it the first openly right-wing novel published by Vargas Llosa (Kristal 1996: 206). It is not uncommon to find statements in different articles asserting that one of the main objectives of the novel was to criticize the Leftist movements in Peru (Torres-Gutiérrez; Allatson 1998: 517; De Grandis 1993: 377-8; Silén 1986: 270). Eduardo Urdanivia went even further when he stated in 1986 that:

Publicar Historia de Mayta en el Perú de hoy, estremecido por la violencia, pauperizado y tocando el fondo de la mayor crisis económica de su historia, no tiene otro objetivo que el de descalificar a la izquierda marxista-leninista como alternativa política en las próximas elecciones presidenciales ${ }^{7}$ (Urdanivia 1986: 140).

Leaving this controversy behind, what the novel is visibly trying to dramatize is that any revolutionary movement based on the dream of a utopian society is doomed, ${ }^{8}$ because it condemns many fine young people to death:

La utopía es eso: la revolución imposible. La idea de que existe una solución final, definitiva y violenta para los problemas. [...] Al mismo tiempo, la novela pretende mostrar la fuerza tremenda de atracción de ese sueño. Lo difícil que es desarraigarlo. La idea de que hay una solución definitiva. La idea de que el paraíso existe y puede ser implantado aquí. Y que todo depende de la inversión

7 Even though Historia de Mayta was published in 1984, and Vargas Llosa did not start in politics until the 1990 elections (when he was a candidate for FREDEMO, right-wing party), the Peruvian writer was already involved in politics as early as 1987, when in several articles and interviews in international journals, he denounced what he called the populist politics of Alan García: "Vargas Llosa: Au Pérou il est en train d'inventer le populisme liberal”, "Voglio la testa di García", "Mario Vargas Llosa contra los vientos de estatización de la Banca”. The most relevant, though, is the manifesto that he published together with some other authors in August, "Frente a la amenaza totalitaria", which was signed by over one hundred personalities of the country (González 2010: 152).

8 In José Alberto Portugal's words, the novel "elabora la crítica del voluntarismo, del gesto prometeico del revolucionario.” (Portugal 1996: 99) 
VALVERDE JIMÉNEZ

de heroísmo, sacrificio y crueldad que uno esté dispuesto a hacer. (Arroyo 1984)

Alejandro Mayta is a character with a very complex personality, but the center of all his different beings, his core, is that he believes, first, in bringing heaven to earth and second, in violence as a means of doing so (Guzmán 1987: 136). An important adjective that defines the character of Mayta is non-conformist. His main aim in life, the one to which he remains steadfast, is to start a real revolution, "una que suprima todas las injusticias y en la que nadie, por ninguna razón, sienta vergüenza de ser lo que es.” (Vargas 2008: 246) As a result of this revolution, a new society would emerge in Peru:

Abolidas las discriminaciones y la explotación, echadas las bases de la igualdad [...] millones de peruanos sentirían que, ahora sí, progresaban, y los más pobres primero [...] cada día se cerrarían un poquito más los abismos que habían separado a proletarios y burgueses, a blancos y a indios y a negros y a asiáticos, a costeños y a serranos y a selváticos, a hispanohablantes y a quechuahablantes [...] (Vargas 2008: 303-304)

His willingness to fight injustice leads him at first to the Church, the only institution that seems to take up the cause of the poor (Vargas 2008: 13). Identifying himself with them, he even decides to follow their meagre diet, ending up in a hospital in his way to starvation (Vargas 2008: 20-21). Soon, however, he loses his faith in a Church (Vargas 2008: 89; 91; 95) that, with the promise of the eternal life, never fights earthly powers to improve the social condition of the poor, "[s]í, muy católico, pero ya no lo soy, ya me liberé de esas ilusiones [...]" (Vargas 2008: 81). Then, he gets disappointed with intellectuals at universities, and finally he becomes a revolutionary, a member of the communist party, who walks all around the city, distributing newspapers among workers in order to start a true social revolution some day in the future (Vargas 2008: $17 ; 20)$.

In this way, the reader observes two kinds of political action in Historia de Mayta: first, institutionalized politics, meaning political parties, political

9 Vargas Llosa himself identifies utopia with the Left, pragmatism with the Right (Vargas 1998: 34), so, from this point of view, stating that the Peruvian writer had an important evolution from an utopian Socialism to the Right politically speaking, as many critics said, does not seem that inaccurate. 
meetings, etc. This is the kind of politics in which Mayta is involved at the beginning of the novel, belonging to a political party that looks for a change using the institutional channels. Second, we find the concept of politics supported by Vallejos, which "consistía exclusivamente en sentimientos, indignación moral, rebeldía, idealismo, sueños, generosidad, mística.” (Vargas 2008: 32) Tired of bureaucracy and of not getting any closer to that utopian society he wishes, Mayta finds new inspiration in Vallejos ${ }^{10}$ and finally decides to follow him in his revolutionary spirit. In the process, he ultimately grows disappointed with institutionalized politics, and decides to be disloyal to his party, becoming an independent revolutionary (Vargas 2008: 213): “[p] olíticamente hablando, era un huérfano total." (Vargas 2008: 181)

Mayta's alternative character in the story is Moisés Barby Leyva, who "[e]n tiempos de Mayta, era un revolucionario de catacumbas; ahora es un intelectual progresista." (Vargas 2008: 41) Moisés describes Mayta as: “[i]dealista, bien intencionado. Pero ingenuo, iluso.” (Vargas 2008: 46) Talking about Mayta's tendency to criticism and disloyalty, he says:

Después se hizo de todo, ésa es la verdad [...] Pero hay que reconocer una cosa añade de pronto, muy serio -. En todos esos cambios no hubo ni pizca de oportunismo. [...] Había en él una tendencia autodestructiva. De heterodoxo, de rebelde orgánico. Apenas se metía en algo, comenzaba a disentir y terminaba en actividad fraccional. [...] ¡Pobre camarada Mayta! Qué destino jodido, ¿no? (Vargas 2008: 46)

Moisés is the kind of revolutionary who in time becomes a member of the establishment, in Mayta's words, "un revolucionario que se «sensualizó»" (Vargas 2008: 43). Noting that Mayta would never have accepted the new standpoint of his old friend, the journalist-narrator reflects, notwithstanding, on how useful his change has been for society from his point of view (Vargas 2008: 43-44). Barbi Leyva has betrayed his former idealism, yes, but in the end he has been able to achieve some positive aspects. Mayta, with his revolutionary action, however, has achieved nothing but dead young soldiers and adolescents, jail, and frustration.

${ }_{10}$ Keeping in mind their differences, Vallejos in this sense reminds us of Jones in Greene's The Comedians, a free spirit who in spite of not being ready to accomplish his revolutionary objectives, is able to inspire people surrounding him, leading them in a revolution destined to fail. 
VALVERDE JIMÉNEZ

The supposedly real Mayta, the one that the journalist meets at the end of the novel, seems to be a very different character from the one recreated in the previous chapters. He has sought his utopia; he has been disloyal to all the institutions with which he has been related; and, as a consequence, he has suffered a long process of disillusionment, beginning with Catholicism (Vargas 2008: 371), then Communism and politics in general (Vargas 2008: 372) and finally, even action and armed conflict. Actually, this last one is not even connected to the failure of Jauja, but with the new betrayal he suffers after his first stay in prison at the hands of those who said they were his comrades, but ended up making him become a common thief (Vargas 2008: 379-383). Thus, the idealist whose first objective was to change the life of the poor people so they could take control of their own destiny, ends up, in the narrator's words, becoming a disillusioned man without any hope for the future:

Tú que tanto creías, que tanto querías creer en un futuro para tu desdichado país. [...] Piensas, o actúas como si lo pensaras, que esto no cambiará nunca para mejor, sólo para peor. Más hambre, más odio, más opresión, más ignorancia, más brutalidad, más barbarie. También tú, como tantos otros, sólo piensas ahora en escapar antes que nos hundamos del todo. (Vargas 2008: 377)

Upon comparing the figures of Alejandro Mayta and León Rivas, one of the main characters in The Honorary Consul, we immediately find many similarities. Both characters have felt very close to the poor. Their lives have been influenced by their commitment to improve the lives of the underprivileged; however their careers are not identical. León Rivas belongs to a bourgeois family, but he, as Mayta, identifies himself with the poor (Greene 1999: 215). As a child, he dreams of becoming such a good lawyer as Perry Mason, who defends the poor and the innocent and always wins (Greene 1999: 28). However, he grows up seeing his father, a good abogado, defending only rich people, making a lot of money, and being part of the upper class. After realizing that he would not become a Latin American Mason, Rivas decides to enter the Catholic Church, the only institution that he thinks helps the poor - exactly what he wants to do (Greene 1999: 217). He enters a seminary, determined to become a priest in a poor neighbourhood so that he can help improve people's lives. Soon he realizes, however, that he has joined the wrong institution: "[...] they [the Fathers] never touched on the horror [...] They saw no problem. They just sat comfortably down in the presence of the horror like the old Archbishop at the General's table and they talked about man's responsibility and Free Will." 
The Search for Utopia and its Consequences

(Greene 1999: 224-225) Leon describes to Fortnum his contradictory feelings about his position in the Church:

[... you are not able to understand how ashamed I felt of the things they made me read to people. [...] "Sell all and give to the poor" - I had to read that out to them while the old Archbishop we had in those days was eating a fine fish from Iguazú and drinking a French wine with the General. [...] The words used to stick on my lips - "Suffer little children", and there the children sat tin the front rows with their pot bellies and their navels sticking out like door knobs.

(Greene 1999: 115-116)

Rivas starts talking in his homilies about controversial issues, such as father Camilo Torres, who is fighting in the mountains on behalf of the poor. As a consequence, Rivas is forbidden to preach (Greene 1999: 117). From this point on, he becomes disappointed with the institution of the Church and decides to abandon it officially. Finally, he follows Fr. Torres' steps, becoming a member of a revolutionary communist guerrilla fighting that is fighting against Stroessner's dictatorship in Paraguay. Like Mayta, Rivas gets involved in a revolutionary action destined to fail. His guerrilla group's objective is not as ambitious as Mayta and Vallejo's, but both revolutionary actions are similar in the composition of both its leaders and its participants. In Rivas' case, he cannot fulfil his role as the leader of the group (when having to kill Fortnum) because he has never really given up his belief in God and everything that belief involves, most importantly in this case, that assassinating another human being does not justify any revolutionary objective. ${ }^{11}$

Another similarity between Alejandro Mayta and León Rivas is that both characters represent anti-heroes. In Mayta's case, it is difficult for him to socialize, he does not dance well and he doesn't feel comfortable when he is too close to a woman. Moreover, his physical appearance is far from the stereotype of the revolutionary: "Mayta era un gordito crespo, de pies planos, con los dientes separados y una manera de caminar marcando las dos menos diez." (Vargas 2008: 13) Moreover, his flat feet give him a hard time when he walks too much

11 From this point of view, Rivas is not that far ideologically from Mayta, who clearly distinguishes between terrorism and revolutionary action: "La acción directa no es terrorismo - dijo Mayta -, sino, pura y simplemente, la acción insurreccional revolucionaria. [...] Guardando las distancias, yo también lo condeno - asintió Mayta -. El terrorismo ciego, cortado de las masas, aleja al pueblo de la vanguardia." (Vargas 2008: 110) 
VALVERDE JIMÉNEZ

(Vargas 2008: 69). ${ }^{12}$ Mayta proves himself an anti-figure of a revolutionary as soon as he gets to the mountains. He suffers from altitude sickness, which does not allow him either to sleep, eat or even concentrate on what Vallejos or Ubilluz have to tell him about the revolution they are preparing (Vargas 2008: 150; 151). Concretely, Ubilluz says about him: "No estaba hecho para la altura. Lo asustaban los precipicios. De dar vértigo, le juro." (Vargas 2008: 173) He is not even able to give a coherent speech to the young students: "Al mal de altura se unía una sensación de ridículo, «itú eres el revolucionario que ha venido a tomar examen a estos camaradas?»” (Vargas 2008: 156) Later, when the moment of action begins, Mayta cannot help feeling sick again, almost to the point of fainting (Vargas 2008: 293). Mayta thinks of himself "[e]ra ridículo estar aquejado de mal de altura. Sentía como si el soroche fuera un lujo inaceptable en un revolucionario. Sin embargo, el malestar físico era muy real: escalofríos, dolor de cabeza, un desasimiento generalizado. Y, sobre todo, ese corazón tronante en el pecho." (Vargas 2008: 315)

In the journalist's portrait of him, Mayta has another feature that makes him different from the traditional figure of the revolutionary, his homosexuality: "Curioso que el personaje sea, una vez más, un antihéroe, un hombre desnaturalizado del imaginario simbólico del guerrillero, y, también, homosexual, con esa otredad extraña y perturbadora que da la diferencia." (Salem 1996: 178)

Greene's León Rivas represents an image that does not resemble the figure of a revolutionary either. In Eduardo Plarr's eyes,

León looked as thin and immature in his T-shirt and jeans as the boy he had known in the country across the border. His brown eyes were too big for his face, the large ears set almost at right angles to his skull made his resemble one of the small mongrel dogs which haunted the barrio of the poor. (Greene 1999: 31)

During the entire kidnapping process, León keeps comforting Fortnum, telling him over and over again that he should not worry, that he will be at home very soon. But what he is trying to do all the time is to comfort himself, trying not to think of the possibility of having to actually kill the British Honorary Consul. When he contemplates that action he becomes frightened (Greene 1999: 113), because he never might have imagined that their kidnapping would end up as a failure: "I never believed it would come to this. You see - if it had been the American Ambassador - they would have given way. And I would

12 This physical detail reminds us again of Jones, in The Comedians, since this is the cause that leads him to death in the end. 
have saved ten men's lives. I never believed I would have to take a life." (Greene 1999: 243-244) When the moment of making the final decision and taking action arrives, Rivas simply finds the way of getting killed before having to assassinate Fortnum, because, as he admits to Plarr before dying,

'Oh, I am safe now,' the voice said.

'Safe?'

'Quite safe. I could not kill a mouse.' (Greene 1999: 250)

The last similarity between the two characters is that both are involved, in reality, in comic fisticuffs. Mayta, Vallejos and Ubilluz, in the main, plan what is supposed to be the beginning of a social revolution in a village in the mountains, an event that will theoretically be supported later in the cities by the communists and the proletariat. Instead of this, for reasons that are never clear, half the members involved in the action never show up, and we witness how Vallejos, Mayta, Cordori, Gonzales, accompanied only by seven teenagers, attempt to form a guerrilla group in the mountains, whose final result is failure and Vallejo's death. Definitely, this is a tragic event, but, considering the amount of absurd elements involved in it, Vargas Llosa turns it into a farce (Chrzanowski 1987: 86).

Curiously enough, Rivas and his men are as amateur as Mayta and Vallejos. They, too, have a poorly-organized plan; and the central act - the kidnapping of the supposed American Ambassador - is surrounded as well by a series of absurd events (they even confuse the American and the British flag) that result in their apprehending a person whom they cannot exchange for any prisoner. However, Greene never turns the entire story into a farce. Different from Mayta and Vallejo, Rivas and his men are aware that they are amateurs. Moreover, they are able to criticize the revolutionary organization to which they belong, represented by el Tigre (Greene 1999: 199). Rivas, the leader, finally disobeys his orders: he rejects the institution and chooses to take the human being's side.

In conclusion, both, Mayta and Rivas take part in a revolutionary action that turns out to be tragic due to the lack of experience of the participants. However, what in Greene becomes heroism and is considered positive in spite of its amateurism (or exactly because of it), in Vargas Llosa becomes nothing but a farce. Mayta is unable to tolerate altitude sickness; he is a failed revolutionary who never reaches the condition of a hero. On the other hand, León Rivas, a revolutionary unable to kill a mosquito, ultimately becomes a hero because of his commitment to the sanctity of human life. 
VALVERDE JIMÉNEZ

Moreover, León Rivas' evolution, as well as Mayta's, is defined, on the one hand, by his own utopian dream, in this case, bringing the Kingdom of God to earth. His second defining feature is his continuous disloyalty, caused by disillusionment. First, he rejects being part of the establishment becoming an abogado; second, he gets separated from the official Church and, finally, he is not able to fulfil his duty as a committed revolutionary. Thus, the image we obtain of both characters' at the end of the story is quite different. Following Vargas Llosa's belief system at the time he wrote and published Historia de Mayta, any action based on a utopia is dangerous and, above all, useless in the process of social change:

Fijarse objetivos inalcanzables es condenar al fracaso los esfuerzos de mejora social. El progreso sólo es imposible cuando la meta está fuera de las posibilidades reales del hombre. Por eso conviene ser menos soñadores, menos ideológicos y más realistas a la hora de encarar los problemas sociales [...] (Vargas 2000: 34)

Bearing this in mind, Mayta's continuous search for his imagined society and his disloyalty to the institutions to which he belonged at some point of his life (that is, the Church, the academia and finally Communism) is considered something totally negative, because it is not practical at all. That means that the image we get of Mayta at the end of the novel is one of someone totally destroyed, ideologically as well as physically. On the contrary, the disloyalty that León Rivas maintains towards the established social system, the Church and finally the institutionalized revolutionary group, based on his utopian desire of bringing this world closer to the Kingdom of God, is considered a virtue, since in Greene's belief system, characters who fight any established institution and commit with humanism are the ones who are valued more positively: "Loyalty confines us to accepted opinions; loyalty forbids us to comprehend sympathetically our dissident fellows; but disloyalty encourages us to roam experimentally through any dimension of sympathy." (Greene 1990: 269)

\author{
Beatriz Valverde \\ beatrizvalverdej@gmail.com \\ Calle Antonio Cañadas, 6 - 4C \\ Guadalajara, 19001 \\ ESPAÑA
}


The Search for Utopia and its Consequences

\section{References}

Allain, M. 1983. The Other Man: Conversations with Graham Greene. London: Bodley Head.

Allatson, P. 1998. Historia de Mayta. A Fable of Queer Cleansing. - Revista de estudios hispánicos, 32, 3, 511-535.

Angvik, B. 1992. La risa que se vuelve mueca, el doble filo del humor y de la risa. Historia de Mayta frente a la crítica en Lima. - Káñina, 16, 1, 91-109.

Arroyo, F. 1984. Mario Vargas Llosa afirma que la ficción literaria "no hace daño", a diferencia de las utopías políticas. - El País, 27.10.

Castañeda, B. 1989. 'El elemento añadido' en Historia de Mayta. - Confluencia, 4, 2, 21-28.

Chrzanowski, J. 1987. Historia de Mayta de Mario Vargas Llosa. - Palabra y el hombre, $63,85-90$.

Couto, M. 1990. Graham Greene: on the Frontier. London: MacMillan.

Couto, M. 1994. The Solitude of the Writer and Political Involvement. - A. F. Cassis, ed., Graham Greene. Man of Paradox. Chicago: Loyola University Press, 413-430.

Cruz, J. 2010. Escribir es servidumbre y gozo. - El País, 7.10.

De Grandis, R. 1993. La problemática del conocimiento histórico en Historia de Mayta, de M. Vargas Llosa. - Revista de Crítica Latinoamericana, 19, 38, 375-382.

González Campaña, N. 2010. Intelectuales y poder en Iberoamérica. Mario Vargas Llosa, el poder como tentación. - Faes. Cuadernos de pensamiento político, http:// www.fundacionfaes.org/record_file/filename/2932/INTELECTUALES Y_PODER_EN_IBEROAMERICA_NURIA_GONZALEZ.pdf (03.01.2012). Greene, G. 1990. Reflections. London: Reinhardt Books.

Greene, G. 1999. The Honorary Consul. London: Penguin Books.

Guzmán, J. 1987. A Reading of Vargas Llosa's “The Real Life of Alejandro Mayta”. Latin American Literary Review, 15, 29, 133-139.

Jouffe, A., Morales Bermúdez, F. 1987. Mario Vargas Llosa contra los vientos de estatización de la Banca. - Cosas, 285, 82-84.

Kristal, E. 1996. A Reading of the Real Life of Alejandro Mayta's Story in the Light of Joseph Conrad's Under Western Eyes. - Antípodas, VIII-IX, 205-215.

Lebrecht, N. 1994. Commitment to Central America and a Passion for Religion. A. F. Cassis, ed., Graham Greene. Man of Paradox. Chicago: Loyola University Press, 385-396.

Pasquini, G. 1987. Voglio la testa di García. - Panorama, XXV, 1121, 102-105.

Portugal, J. 1996. Historia de Mayta; ¿en busca de las raíces del presente? - Explicación de textos literarios, 25, 2, 91-109

Salem, D. 1996. Historia de Mayta de Mario Vargas Llosa; semántica de una ficción ideológica. - M. Domínguez, ed., Historia, ficción y metaficción en la novela latinoamericana contemporánea. Buenos Aires: Corregidor, 177-186.

Sherry, N. 1994. The Life of Graham Greene. Volume Two: 1939-1955. London: Jonathan Cape. 
VALVERDE JIMÉNEZ

Silén, I. 1986. El antimayta. - Revista de Crítica Literaria Latinoamericana, 12, 24, 269-275.

Solera, P. 1994. Semblanza biográfica de Graham Greene. - G. Greene, El poder y la gloria. Barcelona: Círculo de lectores, 306-314.

Sorman, G. 1987. Vargas Llosa: Au Pérou il est en train d'inventer le populisme libéral. - Le Figaro Magazine (International edition), 408, 62-63.

Torres-Gutiérrez, C. 2000. La historia de Mayta: entre lima la horrible y las cumbres de la revolución. - Espéculo. Revista de estudios literarios, 14, http://www.ucm.es/ info/especulo/numero14/mayta.html (03.01.2012).

Urdanivia, B. 1986. Realismo y consecuencias politicas in Historia de Mayta. - Revista de Crítica Literaria Latinoamericana, 11.23, 135-140.

Vargas Llosa, M. 1978. Social Commitment and the Latin American Writer. - World Literature Today, 52, 6-8; 13-14.

Vargas Llosa, M. 1998. Diálogo en Madrid. - Cuadernos Hispanoamericanos, 572, $69-78$.

Vargas Llosa, M. 2000. Socialista, libertario y anticomunista. - Letras libres, 2, 24, $30-34$.

Vargas Llosa, M. 2008. Historia de Mayta. Madrid: Punto de lectura.

Vargas Llosa, M. 2010. Elogio de la lectura y la ficción, http://nobelprize.org/nobel prizes/literature/laureates/2010/vargas_llosa-lecture_sp.html (03.01.2012).

Vargas Llosa, M. et al. 1987. Frente a la amenaza totalitaria. Contra viento y marea, III. - El Comercio, 05.08.

Watts, C. 1997. Greene. Harlow: Pearson.

Whitman, P. 1992. Conversations with Graham Greene. Mississippi: MUP.

Zapata, R. 1988. Testimonio y ficción en la literatura peruana: en torno a la historia de Mayta. - Alba de America, 6, 10-11, 179-185. 